\title{
PLANEJAMENTO PARA CONSTRUÇÃO DE UM ROBÔ QUADRÚPEDE AUTÔNOMO
}

\author{
Talmer Borges Oliveira ; Allan Victor de Rezende ${ }^{2}$; Júlio César Oliveira Ferreira ${ }^{3}$; Gilmar José da Silva \\ Antônio Manoel Batista da Silva \\ 1,2,3,4,5 Universidade de Uberaba (UNIUBE) - Uberaba - Minas Gerais \\ qomputalmer@gmail.com, antonio.manoel@uniube.br
}

\section{1 - Introdução}

Vem aumentando a quantidade de pesquisas para a construção de robôs móveis autônomos, devido à sua potencialidade de aplicação em áreas onde há risco de vida a humanos como a exploração de outros planetas. $O$ enfoque tem sido os robôs com rodas por sua considerável agilidade e velocidade em terrenos com superfície plana. Contudo, o desempenho destes cai em terrenos irregulares ou acidentados (BARASUOL, 2013). Uma alternativa a robôs com rodas são os robôs com pernas. Sistemas de locomoção por pernas são altamente adaptáveis a terrenos irregulares, sendo que requerem apenas alguns pontos de contato com o solo e podem ultrapassar obstáculos com certa facilidade (POTTS, 2011). Sendo assim, esse modelo de robôs é um campo com bastante potencial de estudo. Dentre alguns modelos de robôs com pernas se destacam os quadrúpedes, pois possuem menos graus de liberdade e não são redundantes em comparação com robôs com mais pernas (BARASUOL, 2013). Levando em conta a potencialidade de pesquisa de robôs com pernas, sobretudo quadrúpedes, este projeto refere-se à pesquisa, levantamento bibliográfico e planejamento para posterior construção de um robô quadrúpede autônomo. Pretende-se com esse trabalho estabelecer o plano para o protótipo de um robô quadrúpede autônomo com capacidade de desvio de objetos. O projeto se realizará com a pesquisa para definir o modelo de robô quadrúpede mais viável. Por fim, pretende-se implementar um sistema de geração de movimentos que possibilite ao robô mover-se rapidamente, mas sem danificar sua estrutura.

\section{2 - Materiais e métodos}

Após pesquisa na literatura disponível no que diz respeito a robôs com pernas, sobretudo quadrúpedes, foi constatada a necessidade da abordagem de quatro parâmetros mínimos para sua construção:

- Morfologia do robô

- Modelagem cinemática e dinâmica

- Sistema de geração de movimento

- Sistemas de sensoriamento

\section{1 - Morfologia do robô}

Há dois grupos clássicos de quadrúpedes: mamíferos e répteis. A maioria das pesquisas com robôs com pernas baseia sua morfologia em mamíferos. Em grande parte, isso é devido a certa proximidade biológica com os seres humanos. Todavia, após serem realizados alguns estudos de como alguns mamíferos se locomovem foi possível extrair padrões a serem usados em robôs que imitam sua anatomia (TORRES, 2010).

Em Kretzschmar (2012), o autor optou por seguir a anatomia de um lagarto, ou seja, com as pernas paralelas à plataforma de sustentação do robô. Fazendo uma comparação entre a morfologia baseada em mamíferos e a baseada em lagartos, a referente a mamíferos aumenta a dificuldade do controle dinâmico do robô, pois os pontos de apoio (pés) ficam situados embaixo da plataforma.

Outro parâmetro a se considerar é a quantidade de graus de liberdade de cada perna do robô que influencia em sua modelagem cinemática.

\section{2 - Cinemática e dinâmica}

Ao se projetar um robô quadrúpede surge uma questão pertinente: como controlar as pernas do robô para que este consiga se movimentar com eficiência? Segundo Potts (2011), as pernas de um robô quadrúpede se movendo no ar podem ser vistas como um manipulador de $n$ Graus de Liberdade. Ainda segundo 0 autor, quando ao menos duas pernas estão em contato com o solo, o robô se comporta como um manipulador paralelo. 


\section{3-Sistema de geração de movimentos}

A geração de movimentos em um quadrúpede pode ser contínua e descontínua. A primeira se torna mais complexa, pois exige que as forças resultantes da interação das pernas com o solo compensem o torque realizado pela gravidade. De acordo com González (2006), na geração descontínua, o corpo se move de forma intermitente, obedecendo a um critério básico no qual a projeção horizontal de seu centro de gravidade reside no interior do polígono formado pelas pernas apoiadas ao solo.

\section{4 -Sistema de controle/sensoriamento}

Nos modelos neuro-mecânicos segundo Torres (2010), estes possibilitam a simulação da interação dos modelos com o ambiente físico que os rodeiam, integrando um efeito de realimentação sensorial (visão, tacto). Por meio da detecção de obstáculos e da percepção de superfícies (mediante sensores de toque), é possível implementar um controle que se adeque ao ambiente em tempo real.

\section{3 - Resultados e discussão}

Diante desses itens mínimos para construção de robôs e levando em conta outros fatores, como custo, complexidade e aplicabilidade é proposta a construção de um robô quadrúpede com 9 graus de liberdade com duas juntas em cada perna. Apesar da maioria dos trabalhos relacionados adotar a configuração de pernas com três juntas cada, apenas duas conseguem prover um padrão de movimento adequado. Além do fato de simplificar a modelagem cinemática.

Para tornar possível o desvio de obstáculos é proposto o uso de um sensor de distância do tipo infravermelho. Um acelerômetro de três eixos será utilizado para se estimar velocidade e deslocamento, ajudando a refinar o controle do robô. Em Batista e Cardoso (2007) os autores encontraram dificuldades no uso do acelerômetro. Mas se propõe a usar neste trabalho uma versão mais recente do sensor, o MMA7361L, da Sparkfun Electronics. Este sensor é mais rápido e consome menos corrente em comparação com o utilizado em Batista e Cardoso (2007). Mostra-se necessária também uma calibração mais robusta. Um esboço do protótipo é mostrado na figura 1.

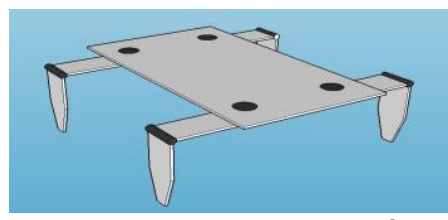

Figura 1: Esboço do protótipo

\section{4 - Considerações finais}

Foi constatado que o controle dinâmico do robô é algo complexo, que requer o uso de cálculos apropriados e conhecimento das forças que atuam sobre a estrutura. Decidimos por buscar o equilíbrio dinâmico empiricamente por meio da avaliação de diferentes tipos de marchas e sequências de passos das pernas. Por fim, concluímos que um autômato finito se mostra como uma solução simples e aceitável para o problema do controle do robô.

\section{5 - Referências}

BARASUOL, V. Um sistema de controle reativo para locomoção de robôs quadrúpedes. Tese de Doutorado, UFSC 2013.

BATISTA, G.F.; CARDOSO, I.F. Adequação de um sistema de locomoção de um robô quadrúpede para avalição de algoritmos de aprendizagem. Trabalho de Conclusão de Curso, Universidade de Brasília 2007.

GONZÁLES, P.; GARCIA E.; ESTREMERA, J. Quadrupedal locomotion: an introduction to the control of four-legged robots. Springer, 2006, 267p.

KRETZSCHMAR, C. Robótica: robô quadrúpede utilizando arduino. Trabalho de Conclusão de Curso, Universidade do Vale do Itajaí 2012.

POTTS, A. S. Modelagem e controle ótimo de um robô quadrúpede. Tese de Doutorado, Universidade de São Paulo 2011.

TORRES, P. T. P. Robôs quadrúpedes: geração de trajectórias em tempo real utilizando sistemas dinâmicos nãolineares. Tese de Mestrado, Instituto Politécnico do Porto 2010.

SPARKFUN ELECTRONICS. MMA7361L. Disponível

em:<https://www.sparkfun.com/datasheets/Co mponents/General/MMA7361L.pdf > Acesso em: set. de 2014 . 